\title{
THE NEPHROTIC SYNDROME IN CHILDREN TREATED WITH A.C.T.H. AND CORTISONE*
}

\author{
BY \\ M. FRANCES MCCALL, ALAN ROSS, BASIL WOLMAN, ANGELA D. BURNS, \\ ELEANOR M. HARPUR and ALTON GOLDBLOOM \\ From the Children's Memorial Hospital, Montreal, and the Department of Pediatrics, McGill University, Montreal
}

(RECEIVED FOR PUBLICATION DECEMBER 28, 1951)

The purpose of this communication is to report seven cases of the nephrotic syndrome in children treated with cortisone and adrenocorticotropic hormone (A.C.T.H.) during the past 15 months. All seven children in this series, with one exception, were males, their ages ranging from 3 to 12 years. In only one child did the disease follow an acute infection. In one other child the syndrome appeared after a skin burn. Marked haematuria was not present at the onset in any case, but in five of the patients red cells were found in the urine on admission and from time to time. Oedema, ascites, oliguria and anorexia were present in all. In one child (Case 1) there was an increase in blood pressure, and in three children (Cases 1, 4 and 7) elevation of the blood non-protein nitrogen (N.P.N.). Serum cholesterol values and erythrocyte sedimentation rates were high in all seven patients, and serum proteins were low, with depression of the albumin fraction to $2 \mathrm{~g}$. or less per $100 \mathrm{ml}$. of serum. In all children the urine showed gross albuminuria and hyaline and granular casts.

The duration of the disease before treatment varied. In the first patient there was a six-month history; in patients 2 and 7, a 21-month and a 30-month history respectively. Patients 5 and 6 had been ill for two to three months, while in patients 3 and 4 the disease had been present for one week only.

\section{Plan of Study}

The children were in hospital for periods varying from one to five months, and were in bed during the entire period of study. They were weighed daily before breakfast, and blood pressure and temperature readings were recorded at least twice daily. The total fluid intake was measured. Blood was drawn weekly for biochemical examination

* These investigations were supported by a grant from the National Research Council of Canada who also supplied the A.C.T.H. and cortisone used in this study. and sedimentation rates in the first four patients, and twice weekly in the remainder. Eosinophil counts were done every two days in the early cases, twice weekly in the later cases. Total white blood counts, differential counts and haemoglobin determinations were followed at frequent intervals.

Complete 24-hour urine collections were attempted in all patients. These were successfully carried out in four of the children who were maintained on diets containing not more than $35 \mathrm{mEq}$ of sodium daily. One child was placed on a diet of known caloric and nitrogen content. Urine determinations included 24-hour excretions of protein, sodium, chloride and water in three patients, and of water, protein, chloride, nitrogen and creatinine in one patient. The urinary excretion of formaldehydogenic steroids was measured from time to time in two patients (Cases 5 and 6).

Cortisone acetate was injected intramuscularly once daily, and was given for a period of 10 days. The total dose varied from 600 to $1,500 \mathrm{mg}$. A.C.T.H. (Armour) was given by intramuscular injection at six-hourly intervals, for periods varying between four days and five weeks. The dose varied from $40 \mathrm{mg}$. to $100 \mathrm{mg}$. daily, and the preparation used was equivalent to the LA-1-A standard.

\section{Methods of Investigation}

Blood chemical studies were made on venous blood before therapy was started and subsequently at weekly or twice-weekly intervals. All colorimetric determinations were made on an Evelyn photoelectric colorimeter. Protein was determined by micro-Kjeldahl digestion followed by Nesslerization (Kolmer and Boerner, 1945). Albumin was determined after precipitation of the globulins with $22 \cdot 3 \%$ sodium sulphate and ether, and globulins by difference (Kingsley, 1942). Sodium was determined colorimetrically as the zinc uranyl acetate 
complex (Albanese and Lein, 1948), and chlorides either by the Volhard procedure (Peters and Van Slyke, 1932) or by the method of Schales and Schales (1941). Total cholesterol was determined by the Liebermann-Burchard reaction (Kolmer and Boerner, 1945) and sugar by the method of Folin and $\mathrm{Wu}$ (1920). Urine protein was determined after precipitation with $10 \%$ trichloracetic acid, urine creatinine by Folin's (Kolmer and Boerner, 1945) method. Urinary corticoids were determined on the total lipid fraction of the urine by the Venning modification (personal communication) of the method of Daughaday, Jaffe and Williams (1948).

Haematological studies were done on capillary blood twice weekly and standard techniques were followed. Sedimentation rates were performed by the method of Wintrobe. Eosinophils were counted frequently during the first few days of therapy and twice weekly subsequently, by the method of Randolph (1949). A nitrogen balance study was carried out on one patient old enough to have adequate bowel and bladder control.
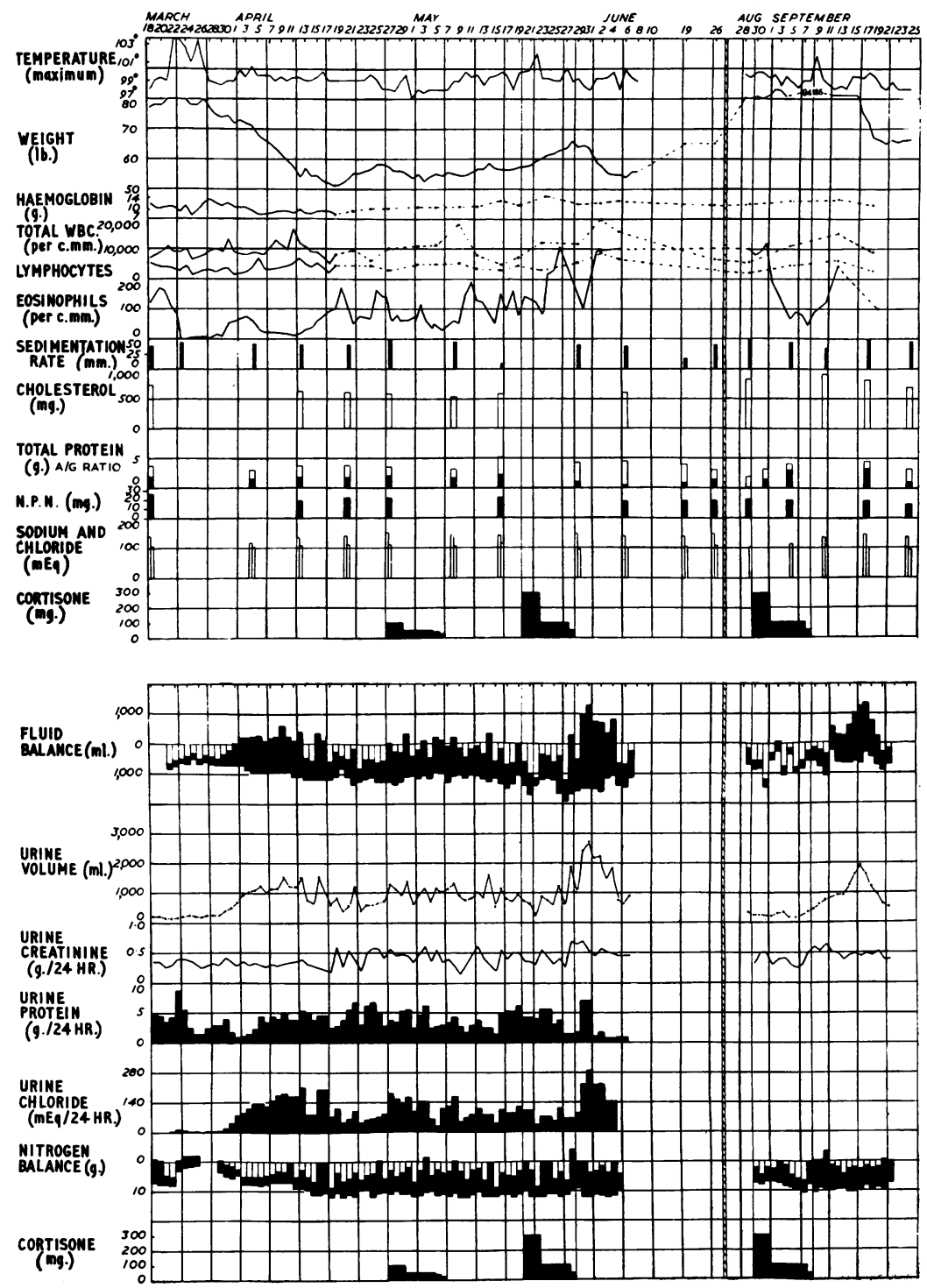

FIG. 1 (top)
FIG. 2 (bottom)
The dietary content of nitrogen and calories was fairly constant and was calculated from standard food tables (Sherman, 1946), the diets themselves being similar to those of Macy (1942). Urine nitrogen and creatinine were determined on daily urine specimens collected from 8 a.m. to 8 a.m. The faecal output of nitrogen was not measured but was assumed to be more or less constant.

\section{Case Reports}

Case 1. S.S., a 6-year-old white boy, was first admitted to hospital in December, 1949. His illness had begun suddenly two months before with oedema and abnormal urinary findings of red blood cells, white blood cells, hyaline and granular casts, and $2,000 \mathrm{mg}$. of albumin per $100 \mathrm{ml}$. The blood pressure was $120 / 90$. The N.P.N. was found to be 51 mg., serum cholesterol $425 \mathrm{mg}$., total serum protein $3 \cdot 2$ g., albumin $1 \cdot 8$ g. and globulin $1.4 \mathrm{~g}$. per $100 \mathrm{ml}$. On re-admission in March, 1950, the picture was essentially the same, and at that time the urea clearance was $89 \%$ of normal. On March 22, while under preliminary observation, he developed pneumonia. This was followed eight days later by a profuse diuresis and a loss of $25 \mathrm{lb}$. in weight (Figs. 1 and 2).

By April some oedema had recurred and he received $600 \mathrm{mg}$. of cortisone over 
a 10-day period. Except for a moderate drop in eosinophils and a loss of $2 \mathrm{lb}$. in weight, the treatment was ineffective (Fig. 1). On May 20 a second course of cortisone was begun, $1,450 \mathrm{mg}$. being administered in nine days. During treatment the weight increased, the blood pressure rose and eosinophils rose after a slight fall. On the last day of therapy diuresis began and was associated with a high output of chlorides (Fig. 2). Albuminuria decreased and the serum albumin level rose. For one month he remained free of oedema and had an excellent appetite. He then reverted to his previous condition. On his third admission in August, 1950, he was again very oedematous, and was given $1,500 \mathrm{mg}$. of cortisone over 10 days. Diuresis began four days after withdrawal of the hormone. The patient lost $18 \mathrm{lb}$. in weight, but on this occasion some oedema remained.

Follow-uP. Oedema recurred, and in a short time he received a fourth course of cortisone to which he did not respond. He again became oedema-free a month or two later following severe cellulitis. He remained relatively well during the winter, but in June, 1951, was in renal failure with many red cells in the urine, haemoglobin of $4 \mathrm{~g}$. \%, a non-protein nitrogen level of $150 \mathrm{mg}$. and a creatinine level of $10 \mathrm{mg}$. per $100 \mathrm{ml}$. of blood. The patient died 20 months after the onset of symptoms. At necropsy the kidneys were moderately overweight with a finely granular surface. There was slight cardiomegaly and evidence of left myocardial hypertrophy. Microscopically the kidneys showed a moderate degree of collapse fibrosis with moderately extensive atrophy of the secretory kidney tubules. The glomeruli were reduced in number. The remainder showed scarring and occasional crescent formation. The normal glomeruli and tubules showed hypertrophy and dilatation. There was a mild interstitial nephritis, focal in character. The arteries and arterioles were normal. The picture was that of early chronic (third stage) glomerulonephritis.

Case 2. M.P., a $3 \frac{1}{2}$-yearold white boy, was admitted on March 21, 1950, with a history of having developed generalized oedema a few days following severe scalding of one arm two years previously. He had had numerous spontaneous diureses, and also a diuresis following measles to which he was intentionally exposed. On admission there was marked oedema, ascites and unilateral hydrothorax, but no hypertension. The urine showed $100 \mathrm{mg}$. of albumin per $100 \mathrm{ml}$., moderate numbers of red cells, white cells and casts. Biochemical values of the serum were as follows: cholesterol 1,239 mg., non-protein nitrogen $37 \mathrm{mg}$., total protein $3.7 \mathrm{~g}$., albumin $1 \cdot 49 \mathrm{~g}$. and globulin $2 \cdot 21 \mathrm{~g}$.

While under observation he developed two rather severe upper respiratory infections, each accompanied by a fall in circulating eosinophils to zero (Fig. 3). Neither of these infections was followed by diuresis. $\mathrm{He}$ was then given cortisone in doses of $100 \mathrm{mg}$. for three days, followed by $50 \mathrm{mg}$. for six days. Eosinophils fell to zero on the fifth day, and there was a slight increase in serum albumin concentration during therapy, but no other response. Urea clearance at this time was $56 \%$ of normal.

Throughout his hospital stay he showed poor response to antibiotics, and eventually died of pneumonia and otitis media. At necropsy the kidneys were slightly overweight and pale, but otherwise grossly normal. Microscopically there was slight focal tubular atrophy and collapse fibrosis, with focal areas of tubular dilatation without inflammation. The reduction in the number of glomeruli was slight. The glomeruli all showed varying degrees of basement membrane thickening and the changes corresponded to those described by Bell (1946) under the term membraneous glomerulonephritis. Proliferative changes were absent.

Case 3. C.A., a $3 \frac{1}{2}$-year-old white boy, had been ill for only one week with slight fever, oliguria and rapidly

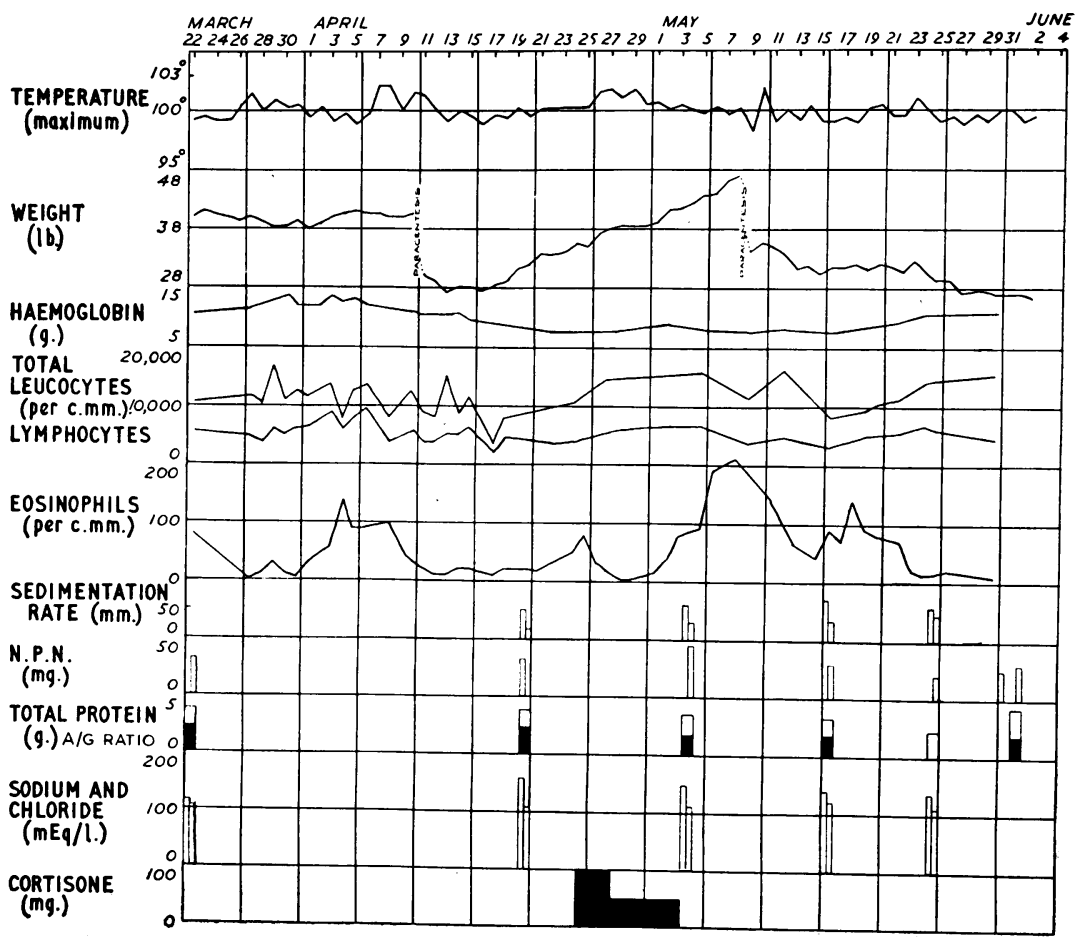

FIG. 3 


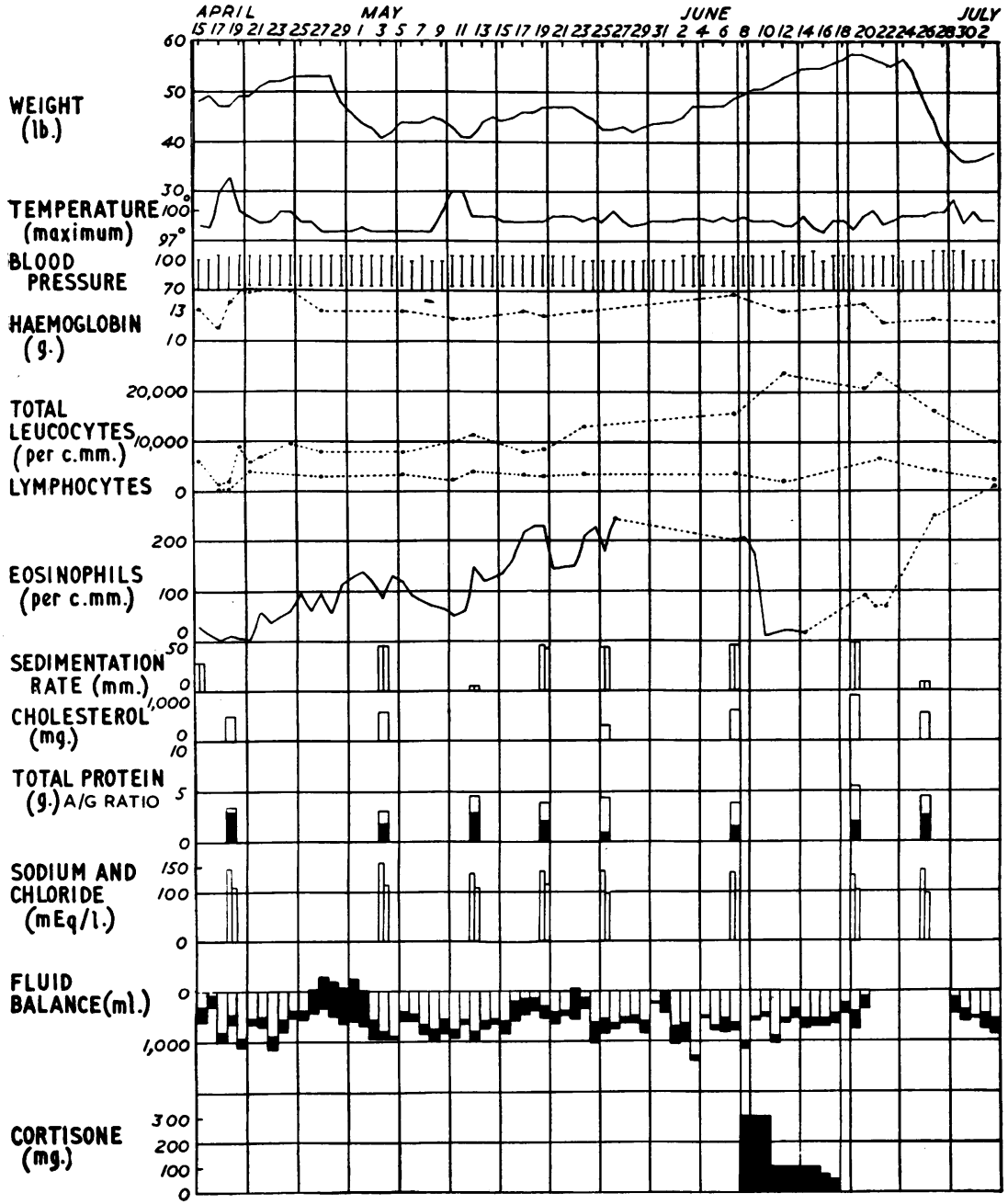

FIG. 4 albumin and cholesterol were within normal limits.

Oedema recurred almost immediately, while serum cholesterol began to rise and serum albumin to decline. The sedimentation rate remained high.

In June, $1,525 \mathrm{mg}$. of cortisone were given over a 10-day period, during which time the values for serum albumin and cholesterol rose sharply. Diuresis occurred eight days after hormone withdrawal, and resulted in complete loss of oedema, and the return of the sedimentation rate to normal. The child was then discharged.

Follow-UP. Three months after therapy, abnormal blood chemical findings were again present. The sedimentation rate was $45 \mathrm{~mm}$., and massive albuminuria and mild pitting oedema of the feet had recurred. Five months after therapy, however, there was no oedema, biochemical abnormality or albuminuria. Over the ensuing 11 months short bouts of oedema recurred several times. The urine on occasion has contained albumin, but at other times has been free of protein. At no time during the 16 months following his one course of cortisone developing oedema and ascites before admission to hospital. On examination there were no abnormal physical findings besides anasarca. The urine contained $500 \mathrm{mg}$. of albumin per $100 \mathrm{ml}$., numerous casts, but no red cells. Serum al bumin measured 0.99 g., globulin 2.47 g., cholesterol $550 \mathrm{mg}$. and non-protein nitrogen $27 \mathrm{mg}$. The sediment ation rate was $27 \mathrm{~mm}$. in the hour.

On April 18, 1950, shortly after admission, the patient developed pneumonia which was accompanied by a low total white count and a fall in eosinophils to zero (Fig. 4). He was treated with aureomycin. For nine days after the onset of infection he showed marked oliguria and continued to gain weight. As the eosinophils reappeared in the circulating blood, the total white count rose. Nine days after the onset diuresis began. The loss of fluid lasted for six days, and resulted in partial loss of oedema. A second febrile episode on May 10 was followed by slighter diuresis 10 days later, at the end of which serum has the child's condition warranted re-admission to hospital.

Case 4. S.F., a 4-year-old boy, was well until one week before entering hospital when he developed fever and oliguria. Oedema developed rapidly and was extreme by June 21, 1950, the date of admission. Albuminuria, hypercholesterolaemia and hypoalbuminaemia were present. The non-protein nitrogen was $54 \mathrm{mg}$., the blood pressure normal and no red cells were found in the urine. A bacterial pneumonia developed soon after admission and abdominal paracentesis was done for relief of distention. On the following day, June 23, cortisone was started; the child received $800 \mathrm{mg}$. in eight days. The child continued to lose weight throughout the period of therapy, due partly to drainage from the paracentesis wound, partly to a mild diuresis which may have resulted from the 
pneumonia. After treatment was stopped there was an increased urinary output for three days, though some oedema remained. The sedimentation rate and the serum cholesterol concentration both fell progressively, and serum albumin showed a marked, but not sustained, rise (Fig. 5). Urea clearance at this time was $76 \%$ of normal.

A second course of cortisone was begun 16 days after the end of the first; the total dose this time was increased to $1,500 \mathrm{mg}$. Urinary output increased during the latter half of therapy, but marked diuresis and weight loss were delayed until the fifth day following the end of treatment. The serum albumin increased during therapy and showed a further increase after cessation. The cholesterol level rapidly fell to normal and the sedimentation rate remained low. Albumin did not disappear from the urine, but was reduced in amount.

Follow-UP. Two months following the second course of therapy there had been no recurrence of oedema, serum albumin was still somewhat low and the urine contained $300 \mathrm{mg}$. \% of albumin. The serum biochemical values gradually returned to normal, and albumin disappeared from the urine for a time, but was again present in small amounts 10 months after discharge. Very mild oedema reappeared in the eighth month following therapy, and again in the twelfth month. These bouts of oedema were accompanied by proteinuria. The child otherwise has remained well and active.

Case 5. P.W., a $2 \frac{1}{2}$-year-old girl, was never entirely well following severe pharyngitis in July, 1950. Oedema appeared two months later, beginning in the feet, and she was admitted to another hospital with anasarca, proteinuria, an elevated sedimentation rate and the following serum biochemical findings: non-protein nitrogen $37.6 \mathrm{mg}$., cholesterol $349 \mathrm{mg}$., total protein $4.8 \mathrm{~g}$., albumin $0.4 \mathrm{~g}$. and globulin $4.4 \mathrm{~g}$. per $100 \mathrm{ml}$. In October, 1950, she was transferred to this hospital for treatment with A.C.T.H. and received $10 \mathrm{mg}$. every six hours for four days, when hormone therapy was stopped because of fever and abdominal pain. Diuresis began 24 hours later, and after 10 days all oedema had been discharged (Fig. 6). 

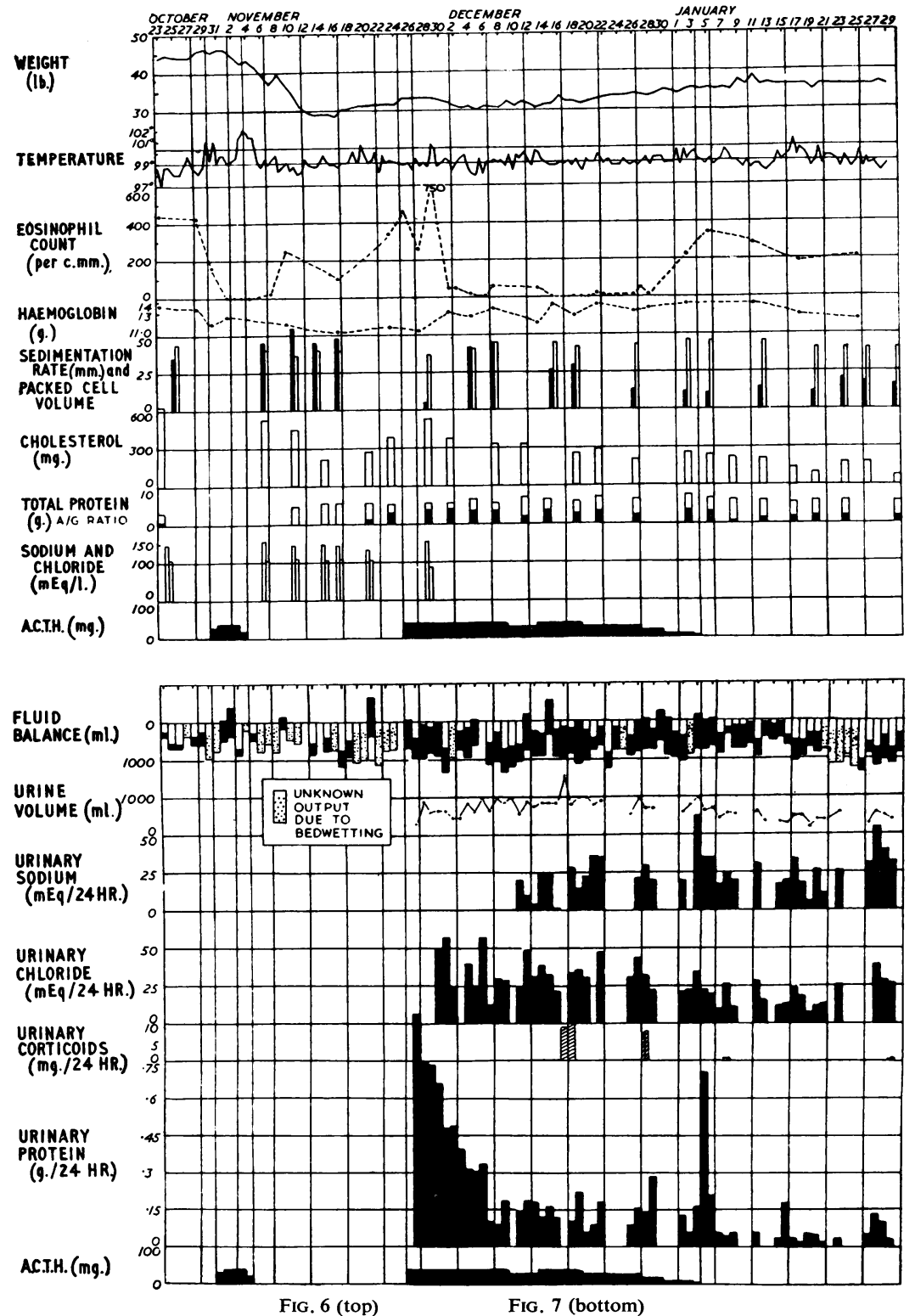

course of A.C.T.H. in doses of $60 \mathrm{mg}$. daily, but only on the fifth day after cessation of therapy. Oedema and haematuria cleared completely, and serum albumin values rose.

In September a six-day course of A.C.T.H. in dosage of $100 \mathrm{mg}$. daily was without effect. However, three weeks later diuresis followed an 11-day period of hormone therapy, the onset occurring on the fourth day after A.C.T.H. was discontinued. At the time of writing 20-30 red cells per high power field are present in the urine. There has been no decrease in proteinuria following therapy, and oedema is beginning to recur.

Case 6. D.L., a white boy of 12 years, was first admitted to this hospital on September 5, 1950, with oedema of eight days' duration, albuminuria and an elevated serum cholesterol and a lowered serum albumin concentration. Without treatment other than restriction of salt he had a spontaneous diuresis, and was discharged free of oedema but with persisting, although diminished, proteinuria and with abnormal, though improved, serum biochemical findings. In November, following repeated sore throats, he was re-admitted, very oedematous and with serum biochemical values which had worsened in the interval (Fig. 8). He was given A.C.T.H. for 10 days in in the urine was accompanied by a temporary increase in the excretion of protein. At this time a urea clearance test showed function to be $110 \%$ of normal.

Follow-up. After discharge from the hospital the patient remained well and oedema-free for three months. Serum albumin then began to fall and proteinuria to increase. In June, 1951, she was re-admitted with oedema, with a serum albumin concentration below 1 g. per $100 \mathrm{ml}$. and an elevated cholesterol level. At this time red cells in small numbers were appearing almost daily in the urine. Diuresis followed a four-day 
was being given. On the last day of therapy urine volume rose steeply, and immediately after the hormone was withdrawn a profuse diuresis of salt and a marked decrease in protein excretion were observed. All oedema fluid was discharged in three days. The child lost $20 \mathrm{lb}$. in weight and at the end of diuresis his severe malmutrition was strikingly apparent.

Eosinophils reached their highest post-treatment value on the third day after therapy was discontinued. On this day the excretion of formaldehydogenic steroids was within normal limits for this patient. During the next two months the serum cholesterol concentration and the sedimentation rate showed a gradual and progressive fall. The serum albumin concentration, which had risen to $3 \mathrm{~g}$. per $100 \mathrm{ml}$. one week following therapy, tended to remain up, though fluctuating a little. Sodium retention did not recur, and on January 26 and 27 added dietary salt was excreted without difficulty. There was at no time any sign of oedema, but the patient ate extremely well and gained $10 \mathrm{lb}$. in weight. Proteinuria did not show further improvement.

In April, 1951, A.C.T.H. was again administered in an attempt to lessen albumin loss through the kidneys. A two-week course was followed by a considerable diminution in proteinuria. After this the patient was discharged, and for six months has remained free of oedema, with normal serum concentrations of albumin and cholesterol, and a normal sedimentation rate.

A mild degree of albuminuria remains.

Case 7. J.S., a 4-year-old white boy, first developed generalized oedema at the age of 18 months. He was admitted to hospital then, and again at 2 years of age, in another city, with the diagnosis of nephrosis. He remained fairly well until February, 1951, when oedema returned for two months. On May 18, immediately after an upper respiratory infection, he was admitted to the Children's Memorial Hospital with puffiness
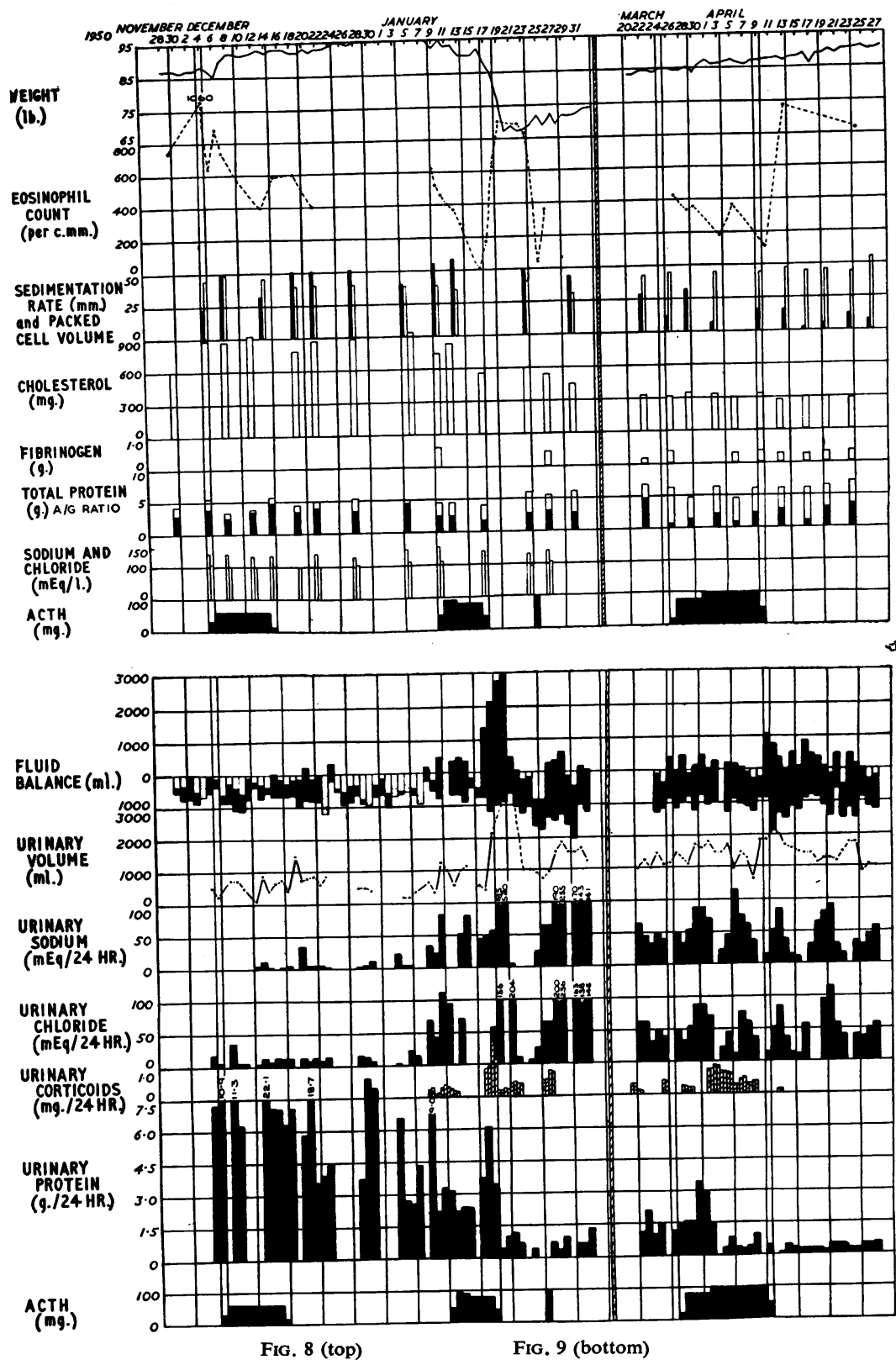

IG. 8 (top)

FIG. 9 (bottom)

of the face and eyelids and moderate ascites. Investigation showed an albuminuria of $1 \mathrm{~g}$. per $100 \mathrm{ml}$. with 1-3 red cells per high power field, hypoalbuminaemia, hypercholesterolaemia and an elevated sedimentation rate. Urinary volume was very low, as was the excretion of sodium and chloride (Figs. 10 and 11).

Five days after admission a spontaneous diuresis occurred, which resulted in a loss of $5 \mathrm{lb}$. weight, partial disappearance of ascites and a fall in serum cholesterol level (Fig. 10). Diuresis lasted four days. On its 


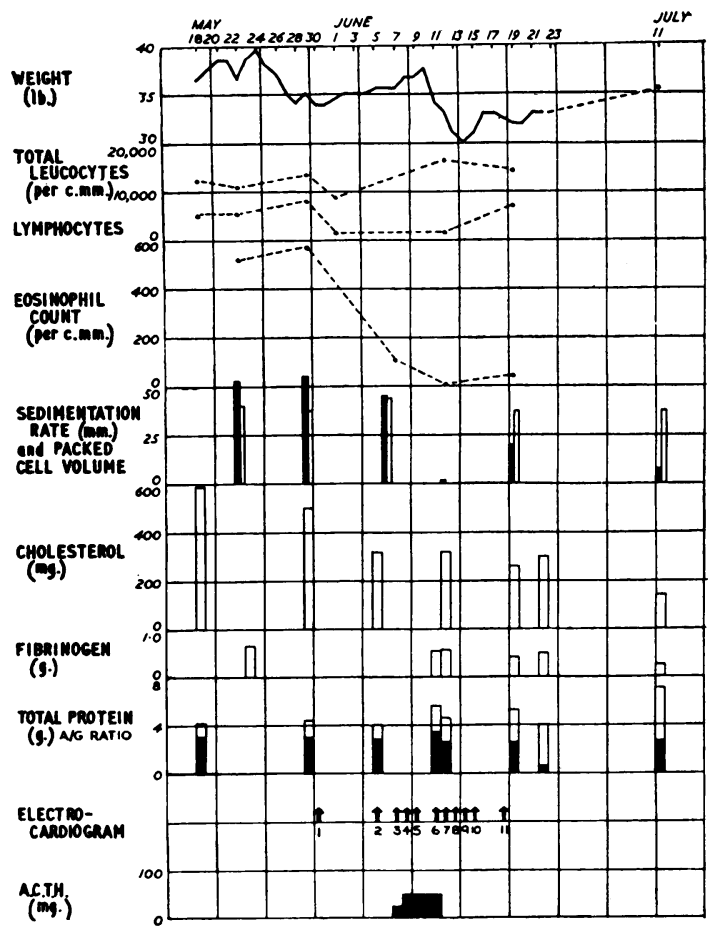

FIG. 10

completion oliguria immediately recurred, as did marked sodium and chloride retention (Fig. 11). A.C.T.H. was given between June 7 and 12. On June 10, after three days' therapy, urinary volume showed a large increase as did the urinary concentration of sodium and chloride, marking the onset of a four-day diuresis. Oedema and ascites had completely cleared two days after therapy was discontinued. A week later serum albumin concentration had returned to normal and proteinuria, though still present, was minimal.

It is noteworthy that on the day A.C.T.H. therapy was started this child seemed weak and listless. Electrocardiograms taken some days before, after his spontaneous diuresis, had shown some depression of T-waves. Repeat readings on June 5 and 7, before any A.C.T.H. had been given, showed almost flat T-waves. There was an immediate response to oral potassium, both clinically and by electrocardiogram. The potassium-excreting effect of A.C.T.H., acting in a period of potassium deficiency following on his spontaneous diuresis, necessitated the giving of relatively large amounts of potassium during therapy in order to prevent the disappearance of T-waves. On June 11 the serum potassium level was only $3 \mathrm{mEq} /$ litre after the child had received $37 \mathrm{mEq}$ of potassium daily since June 8 .

Follow-uP. Following discharge from hospital in June, 1951, the patient remained well. Four months after therapy there was no oedema, the urinary protein loss was $0.23 \mathrm{~g}$. and he was excreting sodium normally. The serum cholesterol measured $288 \mathrm{mg}$. and serum albumin $3 \mathrm{~g}$. per $100 \mathrm{ml}$. Although the patient had had

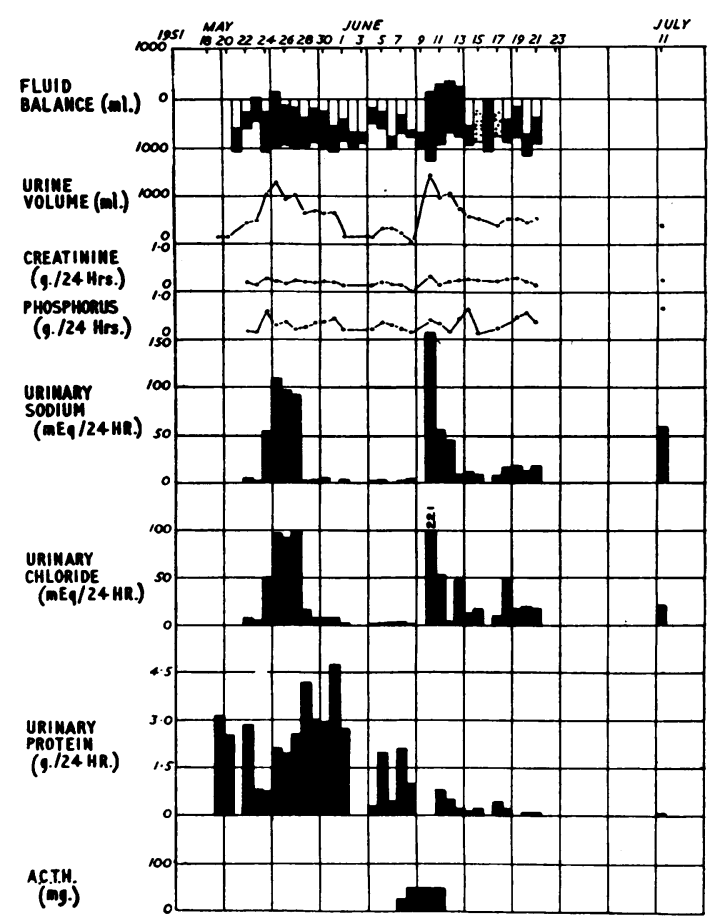

FIG. 11

a number of mild upper respiratory infections he had not re-accumulated oedema.

\section{Results}

Spontaneous Diuresis. Three patients partially or completely lost their oedema following infections while under study (Cases 1, 3 and 7). At the onset of a non-bacterial pneumonia the initial rise in temperature of the patient S.S. (Case 1) was accompanied by a fall in eosinophils to zero (Figs. 1 and 2). Eosinophils remained very low for eight days, at which time urine volume and chloride excretion simultaneously increased and diuresis began. Over the following three weeks all oedema was lost. A slight increase in the concentration of serum albumin and some decrease in the serum cholesterol concentration were observed immediately following diuresis.

C.A. (Case 3) also spontaneously discharged oedema fluid on the ninth day after the onset of a febrile illness (Fig. 4), with resultant partial loss of swelling. Again a temporary increase in serum albumin and fall in serum cholesterol concentrations occurred. These latter changes became even more marked following a second rise in fever which also produced a reduction in eosinophils.

The urinary output of J.S. (Case 7) showed a sudden increase a few days after admission to hospital (Fig. 11). At this time the excretions 
of sodium and chloride rose steeply and remained elevated for several days. Diuresis was not complete, nor were the biochemical values of the serum improved following this spontaneous loss of fluid. It is of interest in this patient that the washing out of potassium occurring during spontaneous diuresis, in conjunction with a low potassium intake due to anorexia, resulted in marked lowering of the serum potassium concentration, electrocardiographic changes, and marked lassitude and weakness.

D.L. (Case 6) also underwent spontaneous diuresis during his first admission to the hospital two months preceding treatment with A.C.T.H. In none of the above cases has spontaneous diuresis resulted in duration of the oedema-free state for more than a few days. It is possible that longer and more marked stimulation of the adrenal is necessary to produce more than transitory loss of oedema, freedom from sodium retention and elevation of serum albumin. Such a strong stimulus may be the mechanism of the diuretic response seen following measles, septicaemia and other severe infections.

Dosage of Cortisone and A.C.T.H. Optimal dosage being unknown, cortisone was administered to the early cases in low doses. Case 1 received $615 \mathrm{mg}$. over a nine-day period, and Case 2 the same amount over a 10 -day period. There was no significant change in the first child's condition during or after therapy (Fig. 1), but one week following withdrawal the sedimentation rate fell suddenly to normal, and the serum albumin concentration was found to have doubled. M.P. (Fig. 3) developed so much increased oedema and ascites that abdominal paracentesis was performed. The nonprotein nitrogen rose to $45 \mathrm{mg}$. per $100 \mathrm{ml}$, serum albumin increased and serum globulin decreased slightly on the day following withdrawal. It was extremely difficult to collect this patient's urine, but it is doubtful if any true diuresis occurred.

A somewhat larger dose was used in Case 4, $800 \mathrm{mg}$. being given over an eight-day period (Fig. 5). Paracentesis had become necessary on the day before therapy began, hence there was no weight gain during cortisone administration. Actual diuresis occurred between the second and fifth days of therapy, possibly as a result of pneumonia contracted 12 days previously. Immediately following withdrawal of the hormone there was an increased urinary output for three days, but no true diuresis. A fall in sedimentation rate and a temporary rise in serum albumin, as well as a slight rise in serum cholesterol concentration occurred.

There having been no diuresis in Cases 1 and 4 as a result of their first courses of cortisone, larger doses were given during the second period of therapy (Figs. 2 and 5). C.A. (Case 3) also received the larger dose during his initial course (Fig. 4). More marked fluid retention occurred during therapy but the ensuing diureses were complete, and weight loss was marked.

A.C.T.H. (Armour) in doses of $40 \mathrm{mg}$. daily resulted in complete diureses in two children, aged 3 and 4 years respectively (Figs. 7 and 10). A daily dose of $60 \mathrm{mg}$. given for 10 days was ineffective in a 12-year-old boy, whereas $80 \mathrm{mg}$. resulted in diuresis (Fig. 9). Later, when this same patient was oedema-free the administration of $80 \mathrm{mg}$. daily had no effect on proteinuria, whereas $100 \mathrm{mg}$. daily reduced the daily excretion of protein from $1.5 \mathrm{~g}$. to $200 \mathrm{mg}$. or less (Fig. 9).

Diuresis. Oedema was not dispersed following three courses of cortisone (Figs. 1, 3 and 5) and one course of A.C.T.H. (Fig. 8) in all of which the dose used was a trial one, and insufficient. Diuresis began between the second and eighth days after withdrawal of cortisone, and as early as the third and fourth days of A.C.T.H. therapy.

Leucocytes. In all cases a substantial rise in the total leucocyte count occurred during cortisone therapy, increases of 7,000 or 8,000 cells per c.mm. being common. The lymphocytes showed a preliminary slight decrease, then either rose somewhat or remained unchanged. The above changes reverted to normal about two weeks after therapy was discontinued. Although not charted, increases in the total leucocyte count occurred similarly in patients receiving A.C.T.H. The A.C.T.H. dosage, which was insufficient to lower the eosinophil count adequately and to produce clinical effects, was also ineffective in raising the total white count. In Case 5, which received A.C.T.H. for six weeks, the total leucocyte count remained consistently at 16,000 until the patient developed an intercurrent infection. With the rise in fever to $100^{\circ} \mathrm{F}$. there was an increase in the white count to 40,000 . A concomitant rise in the eosinophil count to 750 per c.mm. remains unexplained, but may represent a temporary state of relative adrenal hormone lack due to increased demand for hormone during infection. Antibiotic therapy resulted in a rapid fall in fever to normal, and a reduction in the white count to 20,000 and the eosinophils to less than 30 per c.mm.

The infections which resulted in fever, eosinpenia and diuresis in Cases 1 and 3 were not accompanied by any marked rise in the total white count, and were presumably of virus origin. In viral infections, although the adrenal is apparently stimulated, some factor prevents the leucocyte rise which otherwise occurs when circulating eosinophils are markedly depressed. 
Eosinophils. In response simply to fever and infection there occurred an immediate drop in the eosinophil count to levels just above zero. Eosinophils were maintained at low levels for as long as one week following the onset of pneumonia in Cases 1 and 3 (Figs. 1 and 4), and during the various intercurrent infections developing in Case 2 (Fig. 3). However, the administration of $300 \mathrm{mg}$. of cortisone daily for three days did not reduce the eosinophil count below 60 to 70 per c.mm. in two of the children (Figs. 1 and 5). These children had both received a previous course of hormone therapy a short time before. It has been our experience that a second course of hormone may result in less eosinopenia, and may even cause the eosinophils to rise. In a previously untreated child (C.A., Fig. 4), eosinophils virtually disappeared in 48 hours on a dose of $300 \mathrm{mg}$. daily.

High pre-treatment eosinophil counts, as noted by Luetscher and Deming (1950), were seen in three patients (Cases 5, 6 and 7). Two of these had a history of allergy. In D.L. (Fig. 8) the original very high count was present again within a day or two after A.C.T.H. was discontinued. During diuresis the counts tended to return to previous levels, except in the case of spontaneous diureses where low eosinophil levels were seen throughout the period when oedema fluid was being discharged (Figs. 1 and 4).

Sedimentation Rate. The erythrocyte sedimentation rate was uniformly elevated on admission. In three children (Cases 1, 2 and 3) little consistent change occurred during the hospital stay. C.A. (Case 3) showed improvement after leaving hospital, and nine months after discharge had a normal sedimentation rate. Case 4 , on the other hand, showed a gradual progressive diminution in sedimentation rate in response to cortisone (Fig. 5).

The three patients treated with A.C.T.H. have also shown a slow gradual reduction in sedimentation rate. This improvement, in Cases 5 and 6, followed one or more courses of A.C.T.H. given during the non-oedematous stage (Figs. 6 and 8). In both these children a first course of A.C.T.H., which resulted in complete diuresis and was not followed by early relapse, failed to lower the sedimentation rate. In Case 7 , on the other hand, after one course of A.C.T.H., the sedimentation rate fell and has remained normal. Case 6 later relapsed with a return to a high rate, together with other abnormal findings. The sedimentation rate fell again when he responded to re-treatment.

In two patients (C.A. and S.F.), who, after cortisone therapy, are apparently in remission, sedimentation rates were normal nine months after treatment.
Serum Proteins. After cortisone the concentration of serum albumin consistently, though temporarily, increased. This change was usually, though not always, accompanied by a decrease in serum globulin concentration. The increase in serum albumin concentration was usually evident shortly after the cessation of therapy, and there was often a further increase following diuresis. In one child (Case 4, Fig. 5) this initial improvement was maintained, both albumin and globulin being within normal limits at two, six and nine month intervals after discharge. In C.A. (Fig. 4) serum albumin rose following therapy, decreased again soon after, and for the next three or four months remained below $2 \mathrm{~g}$. per $100 \mathrm{ml}$. Six months after therapy it had risen to normal.

All three A.C.T.H.-treated patients showed an increase in serum albumin, two while on therapy and the third after diuresis. Thereafter, although the patients were oedema-free, there was considerable fluctuation in the albumin level. These changes could not be correlated with variations in the haematocrit or in the degree of proteinuria in Case 6. In Case 5 serum albumin rose steadily and remained within normal limits under a prolonged course of A.C.T.H. which reduced proteinuria to a minimum. Improvement was maintained for two months after the end of therapy, when proteinuria increased and the concentration of serum albumin again fell to below $2 \mathrm{~g}$. per $100 \mathrm{ml}$.

An increase in serum albumin was observed following infection in two children who received no hormone therapy. This increase was noted at the end of the period of diuresis, two weeks after the fall in eosinophils which accompanied the initial spike of fever (Figs. 1 and 4).

Serum Electrolytes. No consistent change was noted in either serum sodium or chloride concentrations during or after therapy.

Serum Cholesterol. No consistent change in serum cholesterol concentration was noted during periods of therapy except in Case 5 where prolonged A.C.T.H. therapy resulted in a progressive fall in cholesterol. In all cases except two, however, (Cases 1 and 2), serum cholesterol fell rapidly or slowly to normal, or almost normal values after diuresis had occurred. Case 2 received inadequate therapy, and no change occurred in his weight. Case 5 relapsed later, but in Cases 3, 4, 6 and 7, the cholesterol has remained normal.

Urinary Protein. Cortisone administration appeared to result in a gradual decrease in proteinuria in the one cortisone-treated patient in whom protein excretion was quantitatively measured, the total daily loss in the urine decreasing from $5 \mathrm{~g}$. to 2 g. (Fig. 2). During diuresis, excretion increased 
to pre-treatment levels ( $7 \mathrm{~g}$. protein) for two days, and immediately fell to less than $1 \mathrm{~g}$. per day, a lower protein excretion than at any time during the previous three months. Semi-quantitative tests for urinary albumin in Cases 3 and 4 showed a marked decrease after cortisone was withdrawn, and a further gradual decrease over the following months, with eventual disappearance of albumin from the urine. Proteinuria reappeared in the urine of Case 410 months after therapy, and his urine has been alternately negative and positive for albumin on several occasions since.

A sharp decline in proteinuria was noted for varying lengths of time following diuresis in the A.C.T.H.treated patients. When heavy proteinuria reappeared but before oedema recurred, a prolonged course of A.C.T.H. given to one of the patients (Case 5) caused a gradual decrease in, and virtual disappearance of, protein from the urine (Fig. 7). A similar attempt to abolish proteinuria in the second patient (Fig. 9) was abandoned after 10 days because the patient developed abdominal pain. Protein excretion had by then decreased from $1 \cdot 5 \mathrm{~g}$. to less than $200 \mathrm{mg}$. per day. In both patients the decrease was temporary, and albuminuria again became heavy after three to four weeks.

Urinary Sodium and Chloride. Sodium and chloride retention of some degree is characteristic of nephrosis in the oedematous stage. Failure to excrete chlorides normally was noted early in the period in hospital of Case 1, when only 3 or $4 \mathrm{mEq}$ a day were appearing in the urine (Fig. 2). In this case, during both the diuresis which followed infection and that which occurred after cortisone, there was a great increase in the output of chloride, and marked retention did not recur during the period in hospital.

During the oedematous stage in Case 6 the excretion of sodium and chloride was greatly reduced. Three days before the second course of A.C.T.H. was begun the excretion of these electrolytes suddenly increased. Urine volume also rose, remaining high throughout A.C.T.H. administration. On hormone withdrawal a large diuresis of salt and water occurred. Whether this diuresis was A.C.T.H.induced or was partially due to a spontaneous fluid loss which merely coincided with a period of hormone therapy, is not clear (Fig. 9).

Urinary Corticoids. The excretion of formaldehydogenic corticosteroids was measured in Case 6 before, during and after two short courses of A.C.T.H. The patient had previously been given a course of A.C.T.H. to which he had not responded. Control excretions were within the range expected for a child of his age. On a dose of $80 \mathrm{mg}$., daily excretion of corticoids rose to five or six times control values. The day following withdrawal of therapy excretions were lower than control values, but rose in the three succeeding days to normal (Fig. 9).

Later, the patient did not respond with an increase in corticoid output to a dose of $80 \mathrm{mg}$. of A.C.T.H. administered for five days. When the dose was increased to $100 \mathrm{mg}$., excretion values doubled for three days. Thereafter, with no change in the A.C.T.H. dosage, the amount of corticoids excreted fell to control values. Two days after therapy was discontinued corticoid excretions again were below control values. The excretions of corticoids in this patient did not behave similarly to those reported by Farnsworth (Farnsworth and Dupee, 1951) in patients with nephrosis receiving A.C.T.H. therapy. During the second course of A.C.T.H. the excretions of D.L. (Case 6) were lower than they had been during the first course, even though the dose of A.C.T.H. was somewhat higher during the second course. Farnsworth reports increasing corticoid output during second and third courses of A.C.T.H.

The excretion of these steroids was also measured in Case 5 on several occasions. When the patient was receiving $40 \mathrm{mg}$. of A.C.T.H. daily the amount of corticoids excreted was about ten times the amount excreted in the month following therapy.

\section{Discussion}

There is little knowledge as yet concerning the mode of action of cortisone and A.C.T.H. in the nephrotic state. It is recognized by many observers (Farnsworth, 1950: Thorn, Forsham, Frawley, Hill, Roche, Staehelin and Wilson, 1950; Riley, 1951; Barnett, McNamara, McCrory, Forman, Rapoport, Michie and Barbero, 1950) that A.C.T.H. is capable of producing diuresis in the oedematous patient, either during therapy or following withdrawal. The experience of some investigators (Luetscher and Deming, 1950), as well as that of the present authors, is that similar effects follow the cessation of cortisone therapy. Whether these hormones can influence the nephrotic state apart from precipitating diuresis, by permanently decreasing proteinuria, for example, is not established.

Current concepts of the cause of nephrotic oedema postulate an effort on the part of the kidney to support plasma volume by conserving salt, this saving being an attempt to compensate for the loss of fluid and electrolyte to the tissues which occurs because of lowered plasma osmotic pressure (Bradley, Bradley, Tyson, Curry and Blake, 1950). The conservation of salt is believed to be brought about by increased tubular reabsorption of sodium and chloride, and secondarily of water. In 1948 Farnsworth observed decreased 
excretion of both sodium and chloride in nephrotics. Recently evidence has been presented which suggests that the ability of nephrotic urines to cause sodium retention in adrenalectomized animals may be greater than normal (Luetscher and Deming, 1950). The possibility that in nephrosis there may be an increased production of salt-retaining adrenal hormone is also supported by results of recent tissue analyses. Fox and Slobody (1951) demonstrated that muscle of children who had died of nephrosis contained increased amounts of water, sodium and chloride, but were markedly depleted of potassium. These findings are compatible with over-activity of adrenal cortical hormones with saltand water-retaining effects.

If the mechanisms causing oedema include lowering of plasma osmotic pressure through loss of the albumin fraction of the plasma, and in addition urinary retention of sodium (and of water) to replace electrolyte lost to the serum by passage to the tissue spaces, it would appear that loss of oedema might be brought about by factors opposing the retention of salt, by those favouring its excretion, or by any agent capable of raising the concentration of serum albumin. It is recognized that during the state of adrenal insufficiency sodium is not retained for the body by the kidney. Hence it has been argued that the giving of a synthetic adrenal hormone such as cortisone, which inhibits the release of pituitary A.C.T.H., would, after withdrawal, be expected to result in a state of temporary adrenal insufficiency. That this is at least partially the explanation of the diuresis which follows cortisone withdrawal seems probable (Thorn, Merrill, Smith, Roche and Frawles, 1950; Luetscher and Deming, 1950).

Thorn et al. (1950) have pointed out that although the diuresis which follows withdrawal of A.C.T.H. can be similarly explained, another cause must be sought for the diuresis occurring during A.C.T.H. therapy. It is known that not all adrenal hormones are salt-retaining in their effect, and there is evidence that those of the glucocorticoid type may actually be salt-excreting in action. Hence A.C.T.H., which causes the release of glucocorticoids, may release hormones which compete with the saltretaining type at the kidney tubule. Thorn and his colleagues have also postulated that a kidney tubule, stimulated for some time by A.C.T.H., may eventually become fatigued and no longer able to retain sodium as before. To support this suggestion he cites the decreased sodium retention under deoxycorticosterone acetate (D.O.C.A.) and the failure to respond to pitressin during diuresis, on the part of A.C.T.H.-treated patients.

In the maintenance of plasma osmotic pressure in the nephrotic the amount of albuminuria may be an important factor. Addis, Marmorston, Goodman, Sellers and Smith (1950) showed that experimental proteinuria in the rat could be removed by adrenalectomy, but was aggravated by D.O.C.A. and cortisone. Luetscher and Deming (1950) have shown that nephrotics excrete increased amounts of protein while cortisone is being given, and attribute the decreased proteinuria following withdrawal to relative adrenal insufficiency. Keith, Power, Daugherty and Keith (1950) found an initial increase followed by a decrease in proteinuria while cortisone was being given. Thorn et al (1950a) reported that A.C.T.H. increased proteinuria, but later stated that protein excretion decreased under this hormone (Thorn et al. (1950b). Lauson, Forman, McNamara, Mattar and Barnett (1951) have recently demonstrated decreased permeability of renal glomeruli to protein after treatment with A.C.T.H. In the present report the marked decrease in proteinuria in two patients receiving prolonged courses of A.C.T.H. has been shown.

Another factor which may be concerned in the response of the nephrotic individual to A.C.T.H. and cortisone is the effect which these hormones exert on the serum protein fractions. Hench, Kendall, Slocumb and Polley (1949) first noted that inverted albumin globulin fractions tended to return to normal under cortisone. This was confirmed by Sprague, Power, Mason, Albert, Mathieson, Hench, Kendall, Slocumb and Polley (1950). Thorn (1949) states that D.O.C.A.-like substances tend to cause an increase in the globulin, and a decrease in the albumin fraction of the serum, whereas glucocorticoids produce the reverse effect. The albumin-raising effect of cortisone in nephrosis was noted by Luetscher and Deming (1950) and has been observed by the present authors both in cortisone-treated and in A.C.T.H.-treated patients. The increase in serum albumin concentration begins during hormone administration before diuresis is initiated.

\section{Summary}

Seven children with the nephrotic syndrome were treated, four with cortisone and three with A.C.T.H. Cortisone in doses of 50 or $100 \mathrm{mg}$. daily intramuscularly did not result in diuresis, but when 300 $\mathrm{mg}$. was given for three days, followed by $100 \mathrm{mg}$. for seven days, diuresis regularly ensued. The onset of diuresis occurred from two to seven days after withdrawal of cortisone. Diuresis also followed the administration of A.C.T.H. in doses of $40 \mathrm{mg}$. and $80 \mathrm{mg}$. daily, and began while therapy was being given.

In most instances diuresis was followed by an increase in serum albumin, lowering of serum 
cholesterol, a decrease in proteinuria and a fall in sedimentation rate. In the majority of patients there was a tendency, slight or moderate, to revert to their biochemically abnormal state.

Two patients treated with A.C.T.H. during the oedema-free stage showed marked reduction in proteinuria.

Of the four cortisone-treated patients, one died of an intercurrent infection and another in renal failure. Two are in remission, one completely and the other with albuminuria only.

Of the three A.C.T.H.-treated patients, one shows a persistent tendency to re-accumulate oedema, and has now had five courses of therapy. The other two are apparently well except for moderate proteinuria.

In this small series those patients with the shortest history appeared to respond with a more prolonged and complete remission than patients in whom the disease had been present for longer periods.

An incidental finding of interest was a low serum potassium concentration following spontaneous diuresis. Absent $\mathrm{T}$-waves in the electrocardiograms and marked lassitude accompanied the hypopotassaemia.

\section{REFERENCES}

Addis, T., Marmorston, J., Goodman, H. C., Sellers, A. L. and Smith, M. (1950). Proc. Soc. exp. Biol. Med., 74, 43. Albanese, A. A. and Lein, M. (1948). J. Lab. clin. Med., 33, 246.
Barnett, H. L., McNamara, H., McCrory, W., Forman, C., Rapoport, M., Michie, A. and Barbero, G. (1950). Amer. J. Dis. Child., $80,519$.

Bell, E. T. (1946). 'Renal Diseases,' 1st ed., p. 198. Philadelphia. Bradley, S. E., Bradley, G. P., Tyson, C. J., Curry, J. J. and Blake, W. D. (1950). Amer. J. Med., 9, 766.

Daughaday, W. H., Jaffe, H. and Williams, R. H. (1948). J. clin. Endocr., 8, 166.

Farnsworth E' B (1948). Amer. J. Med, 4. 338.

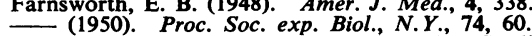

- (1950). Proc. Soc. exp. Biol., N.Y., 74, 60 . of ACTH in the Nephrotic Syndrome.' Proc. 2nd Clin. ACTH Conference (Chicago, 1950), ed. J. R. Mote, Vol. 2, p. 149 . Philadelphia.

Folin, O. and Wu, H. (1920). J. biol. Chem., 41, 367.

Fox, C. L. and Slobody, L. B. (1951). Pediatrics, 7, 186.

Fox, C. L. and Slobody, L. B. (1951). Pediatrics, 7, 186. (1949). Proc. Mayo Clin., 24, 181

Keith, N. M., Power, M. H., Daugherty, G. W. and Keith, H. M. (1950). J. Lab. clin. Med., 36, 843 (abstract).

Kingsley, G. R. (1942). Ibid., 27, 840.

Kolmer'J. A. and Boerner, F. (1945). 'Approved Laboratory Technique,' 4th ed., pp. 807, 831, 833. New York.

Lauson, H. D., Forman, C. W., McNamara, H., Mattar, G. and Barnett, H. L. (1951). "The Effect of ACTH on Glomerular Permeability to Albumin in Children with the Nephrotic Syndrome.' Soc. for Pediatrics Research Meeting. Atlantic City. May, 1951 .

Luetscher, J. A and Deming Q. B. (1950).J. clin. Invest., 29, 1576

Macy, I. G. (1942). 'Nutrition and Chemical Growth in Childhood,' Vol. 1. Baltimore.

Peters, J. P., and Van Slyke, D. D. (1932). 'Quantitative Clinical Chemistry,' Vol. 2. Methods, p. 836. London.

Randolph, T. G. (1949). J. Lab. clin. Med., 34, 1696.

Riley, C. M. (1951). Pediatrics, 7, 457.

Schales, O. and Schales, S. S. (1941). J. biol. Chem., 140, 878.

Sherman, H. C. (1946). 'Chemistry of Food and Nutrition,' 7th ed., p. 620. New York. Sprague, R. G., Power, M. H., Mason, H. L., Albert, A., Mathieson,
D. R., Hench, P. S., Kendall, E. C., Slocumb, C. H. and Polley, H. F. (1950). Arch. intern. Med., 85, 199.

Thorn, G. W. (1949). "The Diagnosis and Treatment of Adrenal

- Insufficiency,' (Amer. Lect. Ser., no. 29), p. 139. Staehelin, D. and Wilson, D. L.'(1950a). New Engl. J. Med., 242, 783.

__, Merrill, J. P., Smith, S., Roche, M. and Frawley, T. F. (1950b). Arch. intern. Med., 86, 319. 